\title{
Factors Influencing Risk Based Internal Audit Adoption In Kenya Agricultural And Livestock Research Organization (Kalro) In Nairobi
}

\author{
Philiph Kiplagat Terer ${ }^{1}$, Solomon Ngahu ${ }^{2}$ \\ ${ }^{1}$ School of Business, Jomo Kenyatta University of Agriculture and Technology.
}

\begin{abstract}
Generally, internal audit has become an indispensable management tool for achieving effective control in both public and private organizations. Therefore this study will seek to establish factors influencing the adoption of risk based internal audit in Kenya and Livestock Research Organization. More specifically the study sought to establish the influence of ICT on risk based internal audit adoption in KARLO. A descriptive research design was employed on a target population comprised of the senior managers in KARLO. A census approach was utilized on a population of 64 senior managers. Questionnaires were used as the main data collection instruments. The collected data was then organized and analyzed using statistical package for social sciences (SPSS) version 24. Data was analysed in form of descriptive statistics and inferential statistics. The study established that ICT infrastructure had positive significant relationship with the adoption of risk base internal auditing. The study concluded that ICT infrastructure have significant influence on the adoption of risk based internal auditing. The study recommended that the board of management should come up with policy measures that will aim at enhancing the adoption of risk based internal auditing. The measures should address the enhancement of ICT infrastructure in the organization.
\end{abstract}

Keywords: Risk, Risk Management, KALRO, Internal Audit, Organization

\section{INTRODUCTION}

Risk-based internal auditing focuses on strategic analysis and business process evaluation (Campbell et al., 2006); and on assessing the goals, risks and controls that must coalesce for an organization's success (Rivenbark, 2000). By identifying, assessing, and monitoring a company's risk, internal auditing helps assure that resources are adequate and focused on priorities (Kunkel, 2004). Generally, risk-based auditing assesses areas of heightened risk (Griffiths, 2006), and, importantly, conducts continuous risk assessments (O'Regan, 2002). The knowledge gained from a comprehensive annual risk assessment, as well as from risk assessments undertaken at the outset of every internal audit engagement, should be shared with management and the board (Jackson, 2005).

Goodwin-Stewart and Kent (2006) assert that internal auditing plays a crucial role in monitoring a firm's risk profile and identifying areas to improve risk management. The objective of internal auditing is to improve organizational efficiency and effectiveness through constructive criticism. Generally, internal audit has become an indispensable management tool for achieving effective control in both public and private organizations. In a study on a sample of Australian and New Zealand firms, Coram et al. (2008) established that organizations with an internal audit function are more likely to detect and self report fraud through misappropriation of assets than those that do not.

In Kenya a study by Kamau (2013) on the determinants of audit expectation gap indicated that there are certain factors that significantly affect the audit expectation gap. He posited that the main reason behind the audit practice is to capacitate the pertinent stakeholders to express an opinion whether or not the financial statements presented reflect a factual and fair picture. As such, the object of any audit is to ensure that financial records on which the auditor is reporting illustrate a true and fair view and are not misleading. According to Mose and Kuloba (2013) in 2013 Kenya insurance industry outlook of the Insurance Regulatory Authority (IRA, 2013) noted that insurance industries have established specialised departments which included amongst others, the internal audit department. This featured as a key success factor to the insurance sector against the backdrop of creation of specialized departments.

In March 2004, the Government of Kenya formally adopted a Risk Based Internal Audit approach following a forum for the Controller and Auditor General and Permanent Secretaries. This was in response to a joint IMF/World Bank report that highlighted the weaknesses of Kenya's internal audit function (Financial Management Anchor, 2008). Same source outlined the following as some examples of the Kenyan success story; a risk based approach in payroll audit has helped Internal Audit identify and resolve significant 
weaknesses in the civil service payroll system, eliminating ghost staff and streamlining payments, has resulted in cost savings. Again in the Ministry of Education (Free primary education), an efficient allocation of limited internal audit resources as a result of adopting a risk based audit approach has also ensured a wider coverage of 18,000 primary schools and introduction of innovative community-based accountability arrangements have been achieved. At the high level risk based internal auditing begins with the normal audit management/planning process which ensures that audit work is completed within schedule and budget. Enterprise wide risk assessment is at the base of Risk Based Internal auditing, forming the cornerstone of RBIA annual plan. Process risk assessments are conducted at the individual internal audit engagements to identify process level risks and assessing the adequacy and effectiveness of internal control system to mitigate those risks (audit execution) (Nuno, Lucia, \& Russel, 2009). A report based on audit findings is submitted to management and /or the audit committee depending on the policy of the organization and appropriate periodic follow ups completes the process. RBIA is a dynamic process and hence always evolving making it difficult to implement as compared to the traditional approach. Monitoring therefore becomes a major challenge given that the audit plan is constantly changing (IIA, 2013).

\section{CONCEPT OF RISK BASED AUDIT}

It is a process, an approach, a methodology and an attitude of mind rolled into one. The simplest way to think about risk-based audit conceptually is to audit the things that really matter to your organizations. Risk based audit (RBA) is a term derived from the Institute of International Audit (II A) research foundation based in the USA (11A. 2004). In 1999 the board of directors of IIA voted to approve a new definition of internal auditing and a new Professional Practice Framework (PPF). The board through deliberation came to a conclusion that a significant gap existed between available guidance and current practice of internal auditing, and that a new framework was needed to carry the profession into the 21 st century (IIA, 2004). Ideally RBA is a paradigm shift from traditional approach of pre-auditing or transactional audit to systems audit and finally to RBA. In pre-audii management abdicated their responsibilities to internal audits; there were no audit reports and no review of the system by management. On the other hand, systems audit was passive and reactive control based audit with no involvement of management in audit planning. Therefore, for internal audit to be effective and efficient, RBA was introduced (IIA, 2004).

Internal Auditing is defined by Institute of Internal Auditors (IIA) as an independent, objective assurance and consulting activity designed to add value and improve an organization's operations. It helps an organization accomplish its objectives by bringing a systematic, disciplined approach to evaluate and improve the effectiveness of risk management, control, and governance processes (IIA, 2003). This definition is designed to embrace the expanding role of internal audit which in recent years has evolved from a narrow focus on control to include risk management and corporate governance (Brody and Lowe, 2000). This definition is used as a framework to develop hypotheses concerning the characteristics of companies that use internal audit, while there is considerable overlap between the areas of risk management, control and governance (Colbert, 2002).

\section{STATEMENT OF THE PROBLEM}

For many years, auditing was confined to assisting organizations to safeguard assets and check established control procedures with the main focus being monitoring and control. Internal auditors on the other hand are tolerated, and have not been deemed essential in organizational control (Spira \& Page, 2003). The emergence of new business risks has compelled many organizations to formulate strategies and to elevate the status of internal auditing (Szpirglas, 2006). Thus, risk-based internal auditing has emerged as an important contributor to effective risk management. Although a shift of internal audit from system based to risk based has been embraced widely with the developed countries taking the lead, prior internal audit research has explored objectivity issues (Brody \& Lowe, 2000), the relationships between internal and external auditors and the trend of outsourcing internal audit activities. Some recent studies have also explored the relationship between internal audit and the audit committee (Goodwin, 2003).

Local and international studies focus mainly on the changing role of audit in ensuring improved performance in organizations. Further, the emergence and dissemination of new audit techniques and methodologies have not received the attention in academic research that is merited by their significance hence creating a knowledge gap. It is in this light that the current study sought to establish the factors that determine adoption of risk based audit in KALRO.

\section{OBJECTIVE OF THE STUDY}

The general objective of the study was to examine the factors that influence the adoption of risk based internal audit in KALRO. Specifically, the study examined the effect of ICT infrastructure on the adoption of risk based internal audit in KALRO. The study was guided by the following research hypothesis. 
$\mathbf{H}_{\mathbf{0}}$ : ICT infrastructure has no statistically significant effect on the adoption of risk based internal audit in KALRO.

\section{RISK-BASED INTERNAL AUDIT THEORY}

Risk-based audit theory argues that clients' specific experience increases an auditor's ability to assess future client risks accurately. However, prior research in psychology suggests that individuals tend to overweigh experience when faced with current risk cues that conflict with experience. This design examines the consequences of prior, positive client-specific experience and efficiency pressure, represented by costly risk cues, on the ability to generate an effective risk assessment. The results indicate that individual's bias toward prior experience. Efficiency results suggest that higher cue costs result in suboptimal risk cue selection, but do not negatively influence risk assessment effectiveness. Risk audit theory argues auditor evaluations during the audit become more effective with client-specific experience (Bell et al. 2005; Bell and Solomon 2002). Rather, there is a risk that auditors will rely on historical client-specific experience, which is backward-looking in nature, in addition to gaining this increased client-specific knowledge.

The risk-based internal audit of the theory is applied to the internal control system and risk management, requiring all departments should establish risk management awareness, identify the risk control points, risk take appropriate measures to control, and recorded a variety of risk control, creating risk-based internal audit of the important sources of data (Doolin and Lawrence, 1997).

According to this theory, responsibility of identifying and managing risks belongs to management, while one of the key roles of internal audit is to provide assurance that those risks have been properly managed (Alexander, 1991). Professional internal audit activity can best achieve its mission as a cornerstone of governance by positioning its work in the context of the organisation's own risk management framework. This involves looking at the way managers identify, assess, respond to and report risks, as well as how well managers monitor how responses to risks are working.

\section{ICT INFRASTRUCTURE AND RISK BASED INTERNAL AUDIT ADOPTION}

David and Liming (2004) discussed on the evolution of auditing in the rapid escalation of technology, which openly contribute to information technology (IT) auditing and internal control standards and guidelines. Technology, information system (IS) and electronic data processing (EDP) have changed the way organizations conduct its business, promoting operational efficiency and aid decision-making.

Iqbal (2005) has explored on the widespread of corporate reporting on the Internet and its implication to auditing profession. The phenomenal growth of Internet ultimately contributes to electronic, web-based Internet reporting information. The author first had revised several literature and accounting standards to understand the nature of best practice and code of conduct for web-based business reporting. The author later had examined Internet reporting practices in Malaysia and set the limit of the study to 100's Kuala Lumpur Stock Exchange Composite Indexed (KLSE CI) companies in Malaysia for year 2003 and 2004. The author found out that there was a significant increase of companies using the internet to supply information to the public. The core activities of disclosing information are mainly on general web page attributes (line of product, business function and product promotional activities), Investor relations, and financial information; including audit reports. The author has suggested that although usage of Internet can benefits the company, reliability and verification of information disclosed has to be guarded. Based on his survey, a large number of the KSLE listed companies (14\%) are hyper-linking audited financial statements to unaudited information. This may contributed to a potential manipulation by the company and influence users in accessing valid and reliable information.

Diamond and Khemani (2005) studied financial management information systems (FMIS) in developing countries. They argued that FMIS design should introduce an improved system of internal and external control for financial management. The internal controls are said to regulate the cycle of recording, analyzing, classifying, summarizing, communicating, and interpreting financial information. The internal audit function, according to the scholars, assists the management in evaluating and assessing compliance with the aforementioned controls. On the other hand, the external control system is exercised through external auditing executed by the supreme audit institution.

A study by Deloitte in 2012, show that information technology is vital element of risk management capabilities and act as a key enabler to an organization's effectiveness and value addition. The value gained from formal risk technology infrastructure are; provide for availability of consistent and reliable risk information, enhance the capabilities of technology infrastructure to support new functional requirements needed by the business and support effective regulatory compliance, increased stress testing and enhanced risk reporting.

Kumsuprom, Corbitt, Pittayachawan and Mingmalairaks (2010) carried a study on ICT risk management in Thai business organizations. The findings from the study is that effective planning of enterprise information technology security is a critical factor that helped organizations to mitigate, prevent and avoid operational, technical and strategic risks related to Information Technology. Straub and Welke (1998) explain 
the nature of information technology risk that affect an organization ranges from physical systems which hinders a firm to deliver goods and services to customers and to computer-based systems which affect a firm from delivering critical information.

Nayak and Mohanty (2009) explain that effective system on risk management usually improves business performance and most companies usually focus on the limited resources they have at their disposal so as to effectively and efficiently control risks, whenever a major problem occurs. Nayak and Mohanty (2009) added that the degree to which a firm can utilize the leverage of its IT risk management processes to exploit commercial business opportunities depends on factors such as governance, product management, customer management, and knowledge management and how each of these processes of the firm in question are matched. The interaction between these generalizations in business processes and a firm's IT risk management process characterizes the company's culture in managing risks.

Ranong and Phuenngam (2009) carried a study on Critical success factors for effective risk management procedures in financial industries. The key factor identified in the study was Information Technology (IT) as a critical factor in the face of increasing competition, higher performance levels, globalization and liberalization. Information Technology (IT) plays a key role in achieving an organization's objectives, enhances business processes, enable shared infrastructure such as knowledge, human assets, core competencies, resources allocation, performance management and communication support.

\section{ADOPTION OF RISK BASED INTERNAL AUDIT}

As a result of changes in organizational needs, technology and complexity of organizations' activities and systems, the nature of services sought from the internal auditors has been transforming over the years from an emphasis on traditional/compliance audit where independence has been the core paradigm, to a value adding role where partnering with management is accorded greater significance (Abdolmohammadi et al., 2006).

The Risk Based Audit is superior to traditional audit approaches for two reasons. First, it focuses on risks, the underlying causes of financial surprises, not just the accounting records. Second, the Risk Based Audit shifts the focus from inspecting the quality of the financial information that is recorded in the financial statements to building quality into the financial reporting process and adding value to the Bank's operations (Gibson, 2003).Allegrini and D'Onza (2003) reported that 25 percent of the top 100 companies listed on the Italian Stock Exchange performed traditional compliance activities and generally followed an audit cycle approach in the annual audit planning process. In 67 percent of their responding companies, internal auditors adopted the model proposed by the Committee of Sponsoring Organizations of the Treadway Commission (COSO, 2004) and mainly applied operational auditing and the risk-based approach at the macro level (annual audit planning). In a few large companies ( 8 percent), auditors applied risk-based approaches both at the macro level and the micro level (individual audit assignments).In January 2005, a study of the development of internal auditing practices in Ireland by the IIA - UK and Ireland (2005) and KPMG Ireland, concluded that 89 percent of heads of internal audit use a risk-based method when preparing annual internal audit plans; 93 percent use a risk-based method in their internal audit assignments; 81 percent liaise with divisional or business heads when compiling their internal auditing plans; 72 percent perform their work in accordance with international standards; and 32 percent are responsible for compliance or risk management. The study concluded that while a large proportion of organisations adopt best practice approaches, there is scope for improvement.

Goodwin-Stewart and Kent (2006) use an agency framework to explore firm characteristics associated with the existence of internal audit function from risk management, control and governance perspectives. He argues that internal auditing is either to be a complementary or substitution mechanism aligns with other risk management and governance mechanisms, and that survey evidence indicates a significant association between the use of internal auditing and a commitment to strong risk management and firm size, however, the results reveal a mixed support for the corporate governance factors.The Public Financial Management Reforms (PFMR) in Kenya forms a critical pillar to Kenya's development goal. The PFMR's strategic objective is to strengthen the Public Financial Management (PFM) systems in order to enhance transparency, accountability and responsiveness of public expenditure to policy priorities. Risk- based audit approach is one of the PFMR's in Kenya aimed at ensuring transparency, accountability and good governance within the Central Government operations. In spite of the above achievements as a result of implementing the risk based audit, the Kenya National Audit Office ( KNAO, 2013) has continually raised significant issues over the same period with regards to the following matters as pertaining to the laid down financial regulations - unsupported expenditure, non-updated bank reconciliation statements, Statement of assets and liabilities, pending bills, un-surrendered imprests warrants, collections of Appropriation in aid and expenditure control.

Mihret and Woldeyohannis (2007) carried out their study on value added role of internal audit. Interview of evidence indicated that as a result of high-staff turnover, the average tenure of auditors is low. Auditors leave the department via transfers to other departments in the corporation. On the other hand, transfers 
into the internal audit department are not significant. This results in more new recruits in the department, which adversely impacts the value-adding potential of internal audit. In addition, the number of staff is not sufficient, given the large size and complexity of the corporation's operations. Effort to ensure provision of appropriate training, such as for certification as internal auditors, is not undertaken in a planned and continuous manner. There is no mechanism to ensure participation of auditors in training on the corporation's design of new systems, improvement of existing ones, and introduction of new services. This denotes that internal audit's value-adding role through involvement in development and revision of systems is limited (Lindow \& Race, 2002). Since the nature of the business is complex and dynamic, providing continuous and focused training would be essential to attain value-adding internal audit results

A study by Kamau (2013) on the determinants of audit expectation gap indicated that there are certain factors that significantly affect the audit expectation gap. He further posited that the main reason behind the audit practice it to capacitate the pertinent stakeholders to express an opinion whether or not the financial statements presented reflect a factual and fair picture. As such, the object of any audit is to ensure that financial records on which the auditor is reporting illustrate a true and fair view and are not misleading. In addition in her study on determinants of adoption of risk-based audit in Kenya's public, Lutta (2012) found that risk-based audit enhances transparency, accountability and responsiveness to public expenditure policy priorities. She further observed that, risk-based audit covers all aspects of financial management.

\section{RESEARCH METHODOLOGY}

The study employed a descriptive survey research design. According to Burns \& Grove (2003), the purpose of research design is to achieve greater control of the study and to improve the validity of the study by examining the research problem. The target population for this study was the senior managers in KALRO. There are 64 senior managers spread across the KALRO institutes in Nairobi. Based on the small size of the population, the researcher opted to adopt a census survey where all the elements in the target population were considered as the study respondents. The study used structured questionnaires that were distributed to the managers of KALRO in Nairobi. The questionnaires contained a five point Likert scale (5-strongly agree, 4agree, 3-neutral, 2-disagree and 1-strongly disagree) to measure the adoption of risk based internal audit.

Data collected was processed and analyzed based on the objectives and research hypothesis using Statistical Package for Social Sciences (SPSS) version 21. This was done using both descriptive and inferential statistics. Descriptive statistics (percentages, frequencies, and means) presented in tables was used to organize and summarize data and to describe the characteristics of the sample while Pearson correlation coefficient was used to check the relationship between variables.

\section{FINDINGS AND ANALYSIS}

The researcher distributed 57 questionnaires to be filled by the respondents of which 51 of them were completely filled and returned. This represented a response rate of $75 \%$ which was characterized as very good. Descriptive statistics on information communication technology infrastructure gave the following results.

Table 1: Respondents views on ICT Infrastructure

\begin{tabular}{|c|c|c|c|c|c|}
\hline & $\mathrm{N}$ & Min & $\begin{array}{l}\mathrm{M} \\
\mathrm{ax}\end{array}$ & $\begin{array}{c}\text { M } \\
\text { ea } \\
n\end{array}$ & $\begin{array}{l}\text { Std. } \\
\text { Dev }\end{array}$ \\
\hline $\begin{array}{l}\text { The institution has an operational website which hosts the } \\
\text { organization profiles and activities }\end{array}$ & $\begin{array}{l}4 \\
8\end{array}$ & 1 & 5 & $\begin{array}{r}3.7 \\
7\end{array}$ & 1.505 \\
\hline $\begin{array}{l}\text { Our audit reports are conveyed on the institutions website for } \\
\text { everyone scrutiny }\end{array}$ & $\begin{array}{l}4 \\
8\end{array}$ & 1 & 5 & $\begin{array}{r}2.5 \\
8\end{array}$ & 1.541 \\
\hline $\begin{array}{l}\text { The institutions website has aided in information storage aiding } \\
\text { future references in the audit process }\end{array}$ & $\begin{array}{l}4 \\
8\end{array}$ & 1 & 5 & $\begin{array}{r}3.9 \\
0\end{array}$ & 1.057 \\
\hline $\begin{array}{l}\text { The company has put up IT security measures to prevent } \\
\text { manipulation of information on its data bank }\end{array}$ & $\begin{array}{l}4 \\
8\end{array}$ & 1 & 5 & $\begin{array}{r}3.6 \\
7\end{array}$ & 1.098 \\
\hline $\begin{array}{l}\text { The organization has also adopted the government recommended } \\
\text { system of IFMIS for financial use tracking }\end{array}$ & $\begin{array}{l}4 \\
8\end{array}$ & 1 & 5 & $\begin{array}{r}4.1 \\
3 \\
\end{array}$ & .914 \\
\hline $\begin{array}{l}\text { The use of ICT has greatly enhanced the audit function in the } \\
\text { organization }\end{array}$ & $\begin{array}{l}4 \\
8\end{array}$ & 2 & 5 & $\begin{array}{r}3.7 \\
7\end{array}$ & .831 \\
\hline $\begin{array}{l}\text { Communications in regard to the audit function is done through the } \\
\text { installed communication system }\end{array}$ & $\begin{array}{l}4 \\
8\end{array}$ & 2 & 5 & $\begin{array}{r}3.9 \\
0\end{array}$ & .905 \\
\hline Valid N (listwise) & $\begin{array}{l}4 \\
8\end{array}$ & & & & \\
\hline
\end{tabular}

It was established that the respondents agreed that the institution has an operational website which hosts the organization profiles and activities with a mean 3.77 (agree). On the other hand they agreed (M=3.9) that the institutions website has aided in information storage aiding future references in the audit process. Further they observed that the company has put up IT security measures to prevent manipulation of information on its data 
bank obtaining a mean of 3.67 (agree). They further agreed that the organization has also adapted the government recommended system of IFMIS for financial use and tracking. The assertion that the use of ICT has greatly enhanced the audit function in the organization and that communication in regard to the audit function is done through the installed communication system was generally accepted with means approximately equal to 4 . Respondents however disagreed that the organizations audit reports are conveyed on the institutions website for everyone scrutiny registering a mean of 2.58 (disagree). The researcher noted that the respondents expressed diverse views in most of the statements registering standard deviations greater than 1 apart from three of the assertions with standard deviation values less than one.

On the other hand, descriptive statistics on the adoption of risk based internal audit gave the results showed in Table 2 below.

Table 2: Views on Credit Performance

\begin{tabular}{|l|c|c|c|c|c|}
\hline & N & Min & Max & Mean & $\begin{array}{c}\text { Std. } \\
\text { Dev }\end{array}$ \\
\hline $\begin{array}{l}\text { The organization has observed audit } \\
\text { compliance by establishing an internal } \\
\text { department in the organization }\end{array}$ & 48 & 1 & 5 & 3.67 & 1.534 \\
\hline $\begin{array}{l}\text { The organization applies risk based } \\
\text { approach in performing risk based } \\
\text { internal audit }\end{array}$ & 48 & 1 & 5 & 3.56 & 1.090 \\
\hline $\begin{array}{l}\text { The internal audit departments budget } \\
\text { is always factored in the organization } \\
\text { yearly budget }\end{array}$ & 48 & 1 & 5 & 3.17 & 1.342 \\
\hline $\begin{array}{l}\text { The organization alligns the internal } \\
\text { audit departments objectives with the } \\
\text { organizational objectives }\end{array}$ & 48 & 1 & 5 & 3.50 & 1.072 \\
\hline $\begin{array}{l}\text { The adoption of internal risk based } \\
\text { audit department is in compliance to } \\
\text { the requirement by the public financial } \\
\text { management reforms }\end{array}$ & 48 & 1 & 5 & 3.35 & 1.263 \\
\hline $\begin{array}{l}\text { The adoption of risk based internal } \\
\text { auditing has enabled optimal utilization } \\
\text { of financial resources due to increased } \\
\text { accountability }\end{array}$ & 48 & 1 & 5 & 3.58 & .986 \\
\hline \begin{tabular}{l} 
Valid N (listwise) \\
\hline
\end{tabular} & 48 & & & & \\
\hline
\end{tabular}

Respondents agreed $(M=3.67)$ that the organization has observed audit compliance by establishing an internal audit department in the organization. Further, they agreed (3.56) that the organization applies risk based approach in performing risk based internal audit. Additionally, respondents were in agreement that the adoption of risk based internal auditing has enabled optimal utilization of financial resources due to increased accountability registering a mean of 3.58 and a standard deviation value of .986 . However respondents were undecided $(\mathrm{M}=3.17)$ on whether the internal audit departments budget is always factored in the organization yearly budget. This means that it is possible that the yearly budget does not factor in the auditing costs of the organization. On the other hand respondents could not conclusively say that the organization aligns the internal audit department's objectives with the organizational objectives. The assertions registered a mean of 3.50 and a standard deviation value of 1.072. Further, respondents were undecided on whether the adoption of internal risk based audit department is in compliance to the requirement by the public financial management reforms registering a mean of $3.35(\mathrm{SD}=1.263)$.

The relationship between ICT infrastructure and adoption of risk based internal audti was established as shown in Table 3 below.

Table 3: Correlations

\begin{tabular}{|l|l|r|r|}
\hline \multicolumn{2}{|c|}{} & \multicolumn{1}{|c|}{$\begin{array}{c}\text { ICT } \\
\text { infrastructure }\end{array}$} & $\begin{array}{c}\text { Auditing } \\
\text { Adoption }\end{array}$ \\
\hline \multirow{3}{*}{ ICT infrastructure } & Pearson Correlation & 1 & $.323^{*}$ \\
\cline { 2 - 4 } & Sig. (2-tailed) & 48 & .025 \\
\cline { 2 - 4 } & $\mathrm{N}$ & $.323^{*}$ & 48 \\
\hline \multirow{3}{*}{ Auditing Adoption } & Pearson Correlation & .025 & 1 \\
\cline { 2 - 4 } & Sig. (2-tailed) & 48 & 48 \\
\cline { 2 - 4 } & $\mathrm{N}$ & & \\
\hline \multirow{2}{*}{$*$. Correlation is significant at the 0.05 level (2-tailed). }
\end{tabular}

The findings indicated the existence of a weak positive significant $(\mathrm{r}=.323, \mathrm{p}<.05)$ relationship between ICT infrastructure and the adoption of risk based internal audit. This shows that the adoption of risk based 
internal audit is interlinked with ICT infrastructure in the organization. Therefore, enhancement of the ICT infrastructure would consequently lead to enhancement in the adoption of risk based internal audit.

Analysis of variance yielded the following results as shown in Table 4.14

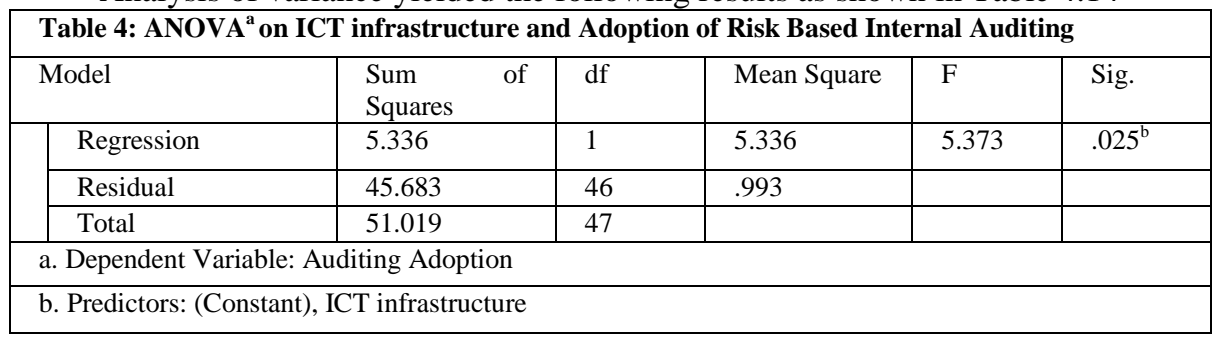

The analysis yielded an $\mathrm{F}$-value $\left(\mathrm{F}_{(1,46)}=5.73\right)$ which was significant at $\mathrm{p}<.05$. This meant that ICT infrastructure has a significant effect on the adoption of risk based internal auditing in KALRO. Therefore, the first null hypothesis that ICT infrastructure has no statistically significant effect on the adoption of risk based internal audit in KALRO was consequently rejected. The researcher concluded that ICT infrastructure has a significant effect on the adoption of risk based internal auditing.

\section{CONCLUSIONS AND RECOMMENDATIONS OF THE STUDY}

In regard to the effect of ICT infrastructure on the adoption of risk based internal auditing, the researcher concluded that there is a significant effect of the ICT infrastructure on the adoption of risk based internal auditing. The researcher observed that the findings indicated that the respondents acknowledged the importance of ICT infrastructure on the adoption of risk based internal auditing. Further, ICT was shown to significantly contribute in explaining the variation in the adoption of risk based internal auditing. Therefore the researcher concluded that ICT infrastructure cannot be ignored as far as the adoption of risk based internal auditing is concerned. The study recommended that the board of management should come up with policy measures that will aim at enhancing the adoption of risk based internal auditing. The measures should address the enhancement of ICT infrastructure in the operations of the auditing department.

\section{REFERENCES}

[1] Campbell, M., Adams, G.W., Campbell, D.R. \& Rose, M.P. (2006), "Internal audit can deliver more value", Financial Executive, January/February, pp. 44-7.

[2] Rivenbark, W.C. (2000), "Embracing risk-based auditing in local government", Government Finance Review, June, pp. 17-20.

[3] Kunkel, J. (2004), "The changing role of internal audit", Chain Store Age, September, pp. 4-5.

[4] Griffiths, D. (2006, March 15). Risk Based Internal Auditing. Retrieved from Risk Based Internal Auditing: http://www.internalaudit.biz/files/implementation/Implementing\%20RBIA\%20v1.1.pdf

[5] O'Regan, D. (2002), "The CPA's transition to the world of internal auditing", The CPA Journal, August, pp. 11-13.

[6] Jackson, R.A. (2005), "Role play", The Internal Auditor, Vol. 62 No. 2, pp. 44-51.

[7] Goodwin-Stewart, J. \& Kent, P. (2006). The relation between external audit fees, audit committee characteristics and internal audit. Journal of finance, 1 (3), 124-41

[8] Kamau, C. G. (2013). Determinants of audit expectation gap: Evidence from limited companies in Nakuru Town. International Journal of Science and Research (IJSR), 2(1), 480-491.

[9] Nuno, C., Lucia, L., \& Russel, C. (2009). Factors associated with the adoption of risk based internal auditing. Managerial Auditing Journal , 79-98.

[10] IIA. (2013, June 12). Risk based internal auditing/risk management/resouces. Retrieved from Chartered Institute of Internal Auditors: http://www.iia.org.uk/resources/risk-management/risk-based-internal auditing/

[11] IIA - UK and Ireland (2003), Risk Based Internal Auditing, Institute of Internal Auditors, Altamonte Springs. FL, available at: www.iia.org.uk,.

[12] Brody, R.G., Lowe, D.J. (2000). The new role of the internal auditor: Implications for internal auditor objectivity, International Journal of Auditing, Vol. 4 No.3, pp. 169-76.

[13] Colbert, S. (2002). A risk driven altitude to the internal audit. Managerial Auditing Journal Vol 10. pp 38-44

[14] Spira, L.F. and Page, M. (2003), "Risk management: the reinvention of internal control and the changing role of internal audit", Accounting, Auditing \& Accountability Journal, Vol. 16 No. 4, pp. 640-61. 
[15] Szpirglas, M. (2006), "Gestion des risques et quiproquos”, Revue Franc,aise de Gestion, February, pp. 67-88.

[16] Goodwin, J. (2003). "The relationship between the audit committee and the internal audit function: evidence from Australia and New Zealand", International Journal of Auditing, Vol. 7 No.3, pp.263-76.

[17] Bell, Timothy B, and Ira Solomon. 2002. Cases in Strategic - Systems Auditing. KPMG LLP, the U.S. member firm of KPMG International, a Swiss nonoperating association.

[18] Doolin.B. \& Lawrence, S. (1997). Manageialism, information technology and health reform in New Zealand.Tje Internationa journal of Public Sector management ,10(1/2), 108-122.

[19] Alexander, L.D (1991), Strategy' implementation: nature of the problem, International Review of Strategic Management, Vol. 2 No. 1, pp.73-91.

[20] Diamond, J., \& Khemani, P. (2005). Introducing financial management information systems in developing countries. IMF Working Paper WP/05/196, 1-32.

[21] Kumsuprom S., Corbitt B. Pittayachawan S. and Mingmalairaks (2010).Determinants ofSuccessful ICT Risk Management in Thai Organizations.pp 107, http://www.pacis.net.org/file/pdf, accessed on 24th March, 2012.

[22] Straub, D.W and Welke, R.J (1998). Coping With Systems Risks: Security Planning Models forManagement Decision Making, MIS Quarterly. No. 20 (4), pp 441-469

[23] Nayak and Mohanty (2009). The Importance of ICT Risk Management in Small to Medium- Sized Enterprises, United Kingdom.Journal for Technology Engineering Sciences.

[24] Ranong P. Phuenngam (2009). Critical Success Factors for effective risk management procedures in financial industries, Umea. Thailand.

[25] Abdol Mohammadi, M.J., Burnaby, P., Hass, S. (2006), "A review of prior common body of knowledge (CBOK) studies in internal auditing and an overview of the global CBOK 2006",Managerial Auditing Journal, Vol. 21 No.8, pp.811-21.

[26] Gibson, M.S. (2003), "Is corporate governance ineffective in emerging markets?",Journal of Financial and Quantitative Analysis, 38 No.1,231-50. IIA (2004), International Standards for the Professional Practice of Internal Auditing, Institute of Internal Auditors, Altamonte Springs, FL.

[27] Allegrini, M., D'Onza, G. (2003), Internal auditing and risk assessment in large Italian companies: an empirical survey, International Journal of Auditing, Vol. 7 pp.191-208.

[28] COSO (2004), Enterprise Risk Management - Integrated Framework, Committee of Sponsoring Organizations, New York, NY, September 29.

[29] Mihret, M. \& Yismaw, F. (2007). Internal audit effectiveness: an Ethiopian public sector case study. Managerial Auditing Journal, 22 (5) 470-484.

[30] Lindow, P.E., Race, J.D. (2002), "Beyond traditional audit techniques", Journal of Accountancy, Vol. 194 No. 1, pp.28-33.

[31] Burns, N. \& Grove, S. (2003). Understanding nursing research. ( ${ }^{\text {rd }}$ Ed.). Philadelphia. PA: W S Saunders. 